\title{
Assessment of Domestic Wood Fuel Utilization and Its Effects in Niger State, Nigeria
}

\author{
Mohammed Kudu Isah ${ }^{1}$, Amina Ahman ${ }^{2}$ \\ ${ }^{1}$ Department of Social Sciences, Kaduna Polytechnic, Kaduna, Nigeria \\ ${ }^{2}$ Department of Languages, Kaduna Polytechnic, Kaduna, Nigeria \\ Email address: \\ Mohammedkudu65@gmail.com (M. K. Isah),am_ahman@yahoo.com (A. Ahman) \\ To cite this article: \\ Mohammed Kudu Isah, Amina Ahman. Assessment of Domestic Wood Fuel Utilization and Its Effects in Niger State, Nigeria. American \\ Journal of Environmental and Resource Economics. Vol. 5, No. 2, 2020, pp. 31-38. doi: 10.11648/j.ajere.20200502.12
}

Received: March 18, 2020; Accepted: April 7, 2020; Published: April 30, 2020

\begin{abstract}
The importance of fire since its discovery has been to provide heat, light, warmth and cooking of food. Increasingly, human population has tasked the resources for making fire through both the traditional and modern processes. However the traditional sources especially among people from developing nations have created social and economic effects. This study assesses wood fuel utilization in Niger State, Nigeria, including the amount consumed, influential factors of consumption and socio-economic effects. The study utilized a mixed method approach to data collection and questionnaire was distributed to 384 household heads that were sampled in the study. Only 20 among the sample were interviewed. The result revealed among others that household size, income, and availability of sources affect consumption while socio-economic impact includes: scarcity of wood fuel resources, increasing distance for wood collection and health hazards. One of the recommendations is that there should be general economic development particularly in urban areas which brings income growth, in order to trigger fuel switching and in variably reduce over dependence on wood fuel sources.
\end{abstract}

Keywords: Wood Fuel, Fuel Wood, Charcoal, Saw Dust

\section{Introduction}

Access to energy is essential for economic and social development. This is why no country developed beyond subsistence economy without ensuring at least minimum access to energy services for a broad section of its population [3]. This makes government of developing countries to prioritize energy services. In Nigeria for instance, wood fuel is a major domestic energy for cooking and heating.

Wood fuel refers to any energy source that comes from woody biomass. These includes fuel wood (or firewood), charcoal, industrial fuel wood, wood pellets, biogas, cellulosic ethanol and other advanced forms of wood fuel energy [17]. Depending on the type, each is transformed into variety of energy sources for use. Fuel wood or firewood consists of any unprocessed woody biomass used to fuel small fire mostly for cooking and warmth. Charcoal is wood fuel made from burning wood in a low-oxygen environment, The dense black substance that results is made up mostly of carbon and produces more heat and energy per kilogram than wood. Industrial fuel wood refers to using a variety of wood fuels for industrial purposes, whether iron smelting or tea processing. Some industries use charcoal, some use saw dust, while others use logs of specific species to achieve precise temperatures.

However, some of the materials collected as fuel wood are already dead and collection rate are typically below regeneration rate. At the same time, there is high demand for wood fuel due to population increase and inadequate supply of electricity to support the entire population [12]. As a result, electricity use for cooking is problematic even for those with access. Hence, majority of the people especially the rural dwellers, cook mostly with wood fuel products, since they cannot afford high cost of petroleum products like gas and kerosene. In recent time, the demand for fuel wood use is more prominent during fuel shortages [24]. The dominance of wood fuel consumption has social implication and constitutes adverse environmental effect.

Consequently, the traditional wood fuel use as energy is leading to forest degradation, deforestation and decline in bio-diversity, soil degradation and atmospheric pollution from emission of Green House Gasses (GHG). Deforestation 
causes soil erosion, risk of floods, desertification on account of deforestation and clearing of woodlands for agriculture and livestock production. All these constitute great concern for environmentalist at macro level. At the micro level the concern ranges from non-sustainability of forest soils for agriculture purposes, health hazards especially during combustion of wood, and indoor air pollution particularly for women during cooking. Accordingly, the extraction, conversion and utilization of various wood fuel based energy have socio-economic implications. This implication has both positive and negative effects depending on the nature of the energy source, wood fuel availability, demand, and the type of technology employed for conversion and use. This effects includes unemployment (wood fuel vendors) created from prevalence of scarcity of wood, reduction in household income and so on.

Nevertheless; socio-economic conditions including increase cost of other energy sources have made the use of wood fuel a convenient source of energy. Hence, exploitation of forest for fuel is on continuous basis. Although, there has been increase in electricity production specifically in hydro and liquefied gas sectors over the years which generally is unaffordable to the poor who comprised of over $80 \%$ of the country's population. Thus, wood fuel continues to be the most popular energy source for many poor people [3]. Niger State which is located in the Guinea Savanna region of Nigeria, is expected to have abundance of wood fuel adequate for use among the people. This study therefore focuses on assessing the effect of domestic wood fuel utilization amongst the people of Niger state. The aim is to generate empirical data to inform policy and practice on issues of global warming and environmental related issues.

\subsection{Statement of the Problem}

Considerable research interest has been generated on topics that shed light on energy crises [23, 25]. However, despite the importance of wood fuel energy sector, there has not been intensive scientific literature on it as most of the information on it are found mostly in technical reports and gray literature [6]. Therefore more information is needed to present facts rather than conjectures and projections. This is because most of these studies are foreign based and not recent. For instance, [2] indicated that the question of measurement of wood fuel is yet to be solved through further studies throughout Sub-Saharan Africa. Also, The International Institute of Tropical Agriculture (IITA) reported that in 2010, deforestation rate in Nigeria translates to a loss of $350,000-400,000$ ha of forest land per year mainly due to biomass energy utilization. In 2015, wood energy statistics, including those of the Food and Agricultural Organization (FAO), were still based on estimates or unofficial sources.

Although Nigeria is blessed with large expanse of land and variant vegetation, wood fuel as an important resource is not sustainably used and managed well. As a result of population increase and high level of deforestation, many households are worried that conflicts would arise as forest products especially wood fuel become increasingly scarce. [26] stressed that Nigerians use about 80 million cubic meters of wood annually for cooking and other domestic uses. These estimates are derived from scattered 1960s household consumption survey based on population and income projections which do not capture the actual reality on ground.

In Niger State, the amount of wood fuel supplied and utilized in relation to sources, and socio-economic effects have not been adequately documented. The lack of reliable information has dwindled adequate understanding of wood fuel situation. It is in the light of the potential negative effects of the changes on social and economic development of the people, that information on the nature and the extent of those changes are needed for adequate energy planning. This study therefore focuses on determining the amount of wood fuel required and supplied in Niger State and to examine the effect of exploitation and use on the well-being of the people of Niger State. As a result, three research questions are raised to guide the study. These include:

1. The quantity of wood fuel energy consumed by household in Niger State.

2. The factors that influence wood fuel consumption.

3. The socio-economic effects of wood fuel energy utilization.

\subsection{Conceptual and Theoretical Frame Work}

Global resource systems involve a wide variety of human activities but typically wood collection forms the basis of rural energy. This wood collection typically faces a tripartite fundamental problem in developing countries which are over-exploitation of wood, extended harvest power and inadequate alternative energy sources [Smith in 8]. Smith added that to be feasible and effective, development efforts must address these 3 concerns simultaneously rather than dealing with 1 or 2 alone. For instance, alleviating one form of stress (a reduction in harvesting capacity), there is tendency to aggravate another stress (perhaps by unemployment). This reality and the complex dynamics imply the need for perspective on sustainable development in global resource system. The issue of wood fuel utilization and its effects in Niger State will consider the PANDA model which means demographic, ecological and economic model. This model explains the factors that drive wood fuel consumption, such as households head income, household size, educational level of household head and habits on the use of energy since most of them are from rural areas. Some that have moved to the urban centre would tend to retain rural habits in relation to energy use. Socio-economic effects of wood fuel utilization in Niger State will also be considered using this model.

The model contains 3 sub models includes demography, economy and wood fuel utilization factors. Demography determines the extent of consumption and provides the labour for production of wood fuel. Income and expenses simulate 
all the income and expense items that could occur in a household mostly, determined by demography, for example; labour availability and educational level of labour. Income is also related to economy especially the production aspect. Expenses are mainly determined by demography, for example; Household size, and their age structure. Expenses can be impacted by production and consumption.

\subsection{Study Area}

The study area is Niger state, which lies between Lat $5^{\circ} 20^{\prime} \mathrm{N}$ and $11^{\circ} 30^{\prime} \mathrm{N}$ and Long $3^{\circ} 4^{\prime} \mathrm{E}$ and $7^{\circ} 30^{\prime} \mathrm{E}$. It is within the middle belt of Nigeria. It is bounded to the north by Kebbi, Zamfara and Kaduna States, to the south by Kwara and Kogi States and to the east by Federal Capital Territory (FCT). Niger state experiences 2 distinct seasons: dry and wet seasons: The annual rainfall varies from $1,600 \mathrm{~mm}$ in the south to $1,200 \mathrm{~mm}$ in the north [16]. The State lies within the double maximum rainfall regime. Raining season duration ranges from 150 to 210 days. Temperature is high throughout the year, averaging about $33^{\circ} \mathrm{C}$ in the warmest month. The state is characterized by tropical continental climate which favours the growth of a diversity of trees which are used for fuel.

The Southern Guinea Savanna vegetation covers the entire landscape of the state. It is therefore characterized by tall grasses and relatively many trees. Along river valleys and where human interference is less, gallery forests occur around the state. Some of the major trees are shear butter trees, locust bean tree, dry land mahogany and a host of other species of trees. In areas bordering rivers, streams and where human settlements are few, traces of rain forest species can be seen. Niger State has a mixture of plant community that vary in composition, diversity, heterogeneity, structure and complexity [11]. Luxuriant vegetation in Niger State provides enough wood fuel for the people.

\section{Method}

A reconnaissance survey was conducted in order to familiarise with the area and to understand the sampling method that was appropriate. This survey was conducted in all the twenty five (25) Local Government Areas (LGA) of Niger State in January, 2019 as a prelude to the actual study. It helps to understand the wood fuel utilization issues in the different LGAs. Even though there is no much difference in their habit of energy use, variation in income level, educational level and population are some of the factors that may create the difference in energy use in the study area. Already there is existing senatorial districts (North, South and East). The study adopts this senatorial arrangement for the study. In all the LGAs, inhabitants complained of various factors that influence the use of wood fuel and the effects of the utilization of wood fuel.

Sample size and Sample Technique

According to National Bureau of Statistics [18] total number of households in Niger State as at 2008 were 715,239 . For this study, 2017 population of Niger State is projected using $2.97 \%$ annual growth rate. The projected population is $5,685,031$. The number of households is determined accordingly, by Using World Health Organisation (WHO) field guide estimate for National Programme on Immunisation (NPI) of 5.9 persons per households. Thus the total number of households in Niger State using 2017 population is estimated as 963,565 household heads which represents the population of this study. This sample there by equates to 384 on the [13] sampling table. According to [13], if target population is between 250,000 and 3,000,000,000 then a sample of 384 is appropriate for this study. See Table 1 below for the distribution of the sample.

Table 1. Sample LGAs and Households.

\begin{tabular}{llll}
\hline Zones & LGAs & Sampled Households & Percentage \\
\hline \multirow{3}{*}{ Zone A } & Agaie & 31 & 8.07 \\
& Bida & 42 & 10.93 \\
& Lavun & 50 & 13.02 \\
\multirow{2}{*}{ Zone B } & Bosso & 36 & 9.38 \\
& Paikoro & 38 & 9.90 \\
& Suleja & 69 & 17.97 \\
\multirow{2}{*}{ Zone C } & Agwara & 17 & 4.43 \\
& Kontangora & 50 & 13.02 \\
& Rijau & 51 & 13.28 \\
& Total & 384 & 100.00 \\
\hline
\end{tabular}

Source: field Survey, Niger State, 2019.

The table 1 indicates the sample size obtained from each of the three (3) LGAs in the zones. Households sample from each LGA involved the household heads which was selected through a simple random sampling. The 384 households head that were selected in the districts was done proportionate to the size of the population of the districts. Thus, 123 household's head for the south, 143 for East and 118 for North which is the same as Zones A, B and C respectively.

\section{Results and Discussion}

This section includes presentation and the analysis of the data obtained from the field as well as the interpretation of results. This is arranged based on the research questions. The presentation starts with the socio-demographic characteristics of households, followed by the quantity of wood fuel energy consumed by households, factors that influence wood fuel consumption in Niger State and; the socio-economic effects of wood fuel energy utilization in Niger State.

\subsection{Demographic Characteristics of the Participants}

The findings indicate that Males forms majority (99.5\%) of the households' head, only two female recognized were the household head out of the 384 respondents. This is true because most of them did not respond to questions as expected. More than average of the respondents are married $(82.8 \%), 169(44.0 \%)$ are respondents within the age group of 40-49 years and so they form the major age group in this 
study. See the Table 2 below for the distribution of the responses on the household characteristics:

Table 2. Distribution of Households 'Socio-Demographic Characteristics.

\begin{tabular}{|c|c|c|c|}
\hline Variables & Categories & Frequency & Percentage \\
\hline \multirow{5}{*}{$\begin{array}{l}\text { Household } \\
\text { Size }\end{array}$} & $1-5$ & 187 & 48.8 \\
\hline & $6-10$ & 105 & 27.3 \\
\hline & $11-15$ & 50 & 13.1 \\
\hline & Above 15 & 41 & 10.7 \\
\hline & Total & 384 & 100.00 \\
\hline \multirow{6}{*}{$\begin{array}{l}\text { Educational } \\
\text { Level of } \\
\text { Household } \\
\text { Head }\end{array}$} & Qur'anic only & 24 & 6.25 \\
\hline & Primary & 49 & 12.76 \\
\hline & Secondary & 126 & 32.81 \\
\hline & $\mathrm{OND} / \mathrm{NCE}$ & 100 & 26.04 \\
\hline & HND / Degree and above & 85 & 22.14 \\
\hline & Total & 384 & 100.0 \\
\hline \multirow{6}{*}{$\begin{array}{l}\text { Occupation of } \\
\text { Household } \\
\text { Head }\end{array}$} & Civil Servant & 297 & 78.2 \\
\hline & Business & 46 & 12.1 \\
\hline & Former & 22 & 5.8 \\
\hline & Artisan & 6 & 1.6 \\
\hline & Others & 9 & 2.4 \\
\hline & Total & 380 & 100.0 \\
\hline \multirow{7}{*}{$\begin{array}{l}\text { Monthly } \\
\text { Income of } \\
\text { Household } \\
\text { Head (to the } \\
\text { nearest 1000) }\end{array}$} & $1,000-10,000$ & 37 & 9.8 \\
\hline & $11,000-20,000$ & 42 & 11.1 \\
\hline & $21,000-30,000$ & 19 & 5.0 \\
\hline & $31,000-40,000$ & 15 & 4.0 \\
\hline & $41,000-50,000$ & 110 & 29.2 \\
\hline & Above 50,000 & 154 & 40.8 \\
\hline & Total & 377 & 100.00 \\
\hline
\end{tabular}

Source: field Survey, Niger State, 2018.

The result on Table 2 above indicate that the household size of between 1-10 members form the major part of the respondent households' size (76.1\%). Based on educational qualification, all the respondents are educated with differing levels of education. Majority of the households' head are civil servants (Public Servant - working for government pay), 297 (78.2\%) are working with government. Majority of the households' head have monthly income above the poverty line of $\$ 1$ per day since out of the 377 respondents only $37(9.8 \%)$ have daily income below the poverty line of $\$ 1$ per day (one dollar is equivalent to N360; Nigerian Naira).

\subsection{Quantity of Wood Fuel Used by the Households}

This is the amount of wood fuel that is used for energy by the households in Niger State. It is the energy use per se. [5] in re-assessing the fuel wood situation in developing counties concluded that though use of wood fuels is generally not growing at the rate assumed in the past, the quantities used, and the number of people using them, are still huge. Moreover, in the main consuming regions these magnitudes will often continue to be very large. [5] also estimated that in Africa, the number of people using fuel wood and other biomass fuel will rise by more than $40 \%$ between year 2000 and 2030 to about 700 million.

Table 3. Quantity of Fuel Wood (firewood) used by the household per week.

\begin{tabular}{lll}
\hline Bundles & Frequency & \% \\
\hline 1-3 bundles & 130 & 61.0 \\
4-6 bundles & 49 & 22.8 \\
Above 6 bundles & 34 & 16.2 \\
Total & 213 & 100.00 \\
\hline
\end{tabular}

Source: field Survey, Niger State, 2018.

Table 3 shows the quantity of fuel wood used by the households, it thus shows that 130 households representing $61.0 \%$ consumed about 1-3 bundles weekly, 49 households (22.8\%) used about 4-6 bundles weekly, and 34 households $(16.2 \%)$ used above 6 bundles. It however, shows that most of the households used an average of 1-3 bundles of fuel wood. It is therefore, concluded that there is an average demand (consumption) of 1-3 bundles of fuel wood by most of the people in Niger State. The weight of a bundle of fuel wood (fire wood) In Niger State varies from one place to another but the average bundle observed from the field is about $18 \mathrm{~kg}$. Deduced from this study is that while some households used very few bundles, some used up to eight (8) bundles a week. If the average bundle of fuel wood per week is 1-3 bundles, it will suffice to say that the households used between $18 \mathrm{~kg}$ and $54 \mathrm{~kg}$ a week (weight of a bundle multiply by average bundles).

From the interviews, frequent power cuts increase the demand for fuel wood and as a result more bundles are used. Though in most cases the amount of bundles used is also a function of the size of the household and the number of activities (energy involving) that the household indulge in. The amount of fuel wood used is also dependent on whether it is the main energy source or not. Households that use fuel wood as the main energy source will require more than households that use it as supplement.

Table 4. Quantity of Charcoal used by households per week.

\begin{tabular}{lll}
\hline Quantity (Bag) 1 kg & Frequency & \% \\
\hline $1-5$ & 55 & 27.1 \\
$6-10$ & 80 & 39.1 \\
$11-15$ & 45 & 22.2 \\
Above 15 & 24 & 11.6 \\
Total & 204 & 100.00 \\
\hline
\end{tabular}

Source: field Survey, Niger State, 2018.

Evident from this study (Table 4), the quantity of charcoal used by households per week indicates that 55 households (27.1\%) uses between 1-5 bags, 80 households (39.1\%) use between 6-10 bags, 45 households $(22.2 \%)$ use between 1115 bags and 24 households (11.6\%) use above 15 bags of charcoal per week. When some of the households were interviewed, they indicates that most households in urban areas use more charcoal and consumption varies amongst the households as a result of income variation, inadequacy of modem sources, size of households and so on. Majority of the rural households uses less of charcoal and this is as a result of availability of fuel wood which is collected free from the environment.

\subsection{Factors Influencing Wood Fuel Energy Demand}


This section identifies the factors that influence wood fuel energy demand in the household in Niger State. Energy technology used by the households is a function of its socioeconomic status $[10,22]$. Most of these studies generalized the result by highlighting the importance of the role played by socio-demographic and sometimes cultural characteristics in choosing and determining main and secondary energy sources, on top of the relationship between price, demand and income. In this way, energy consumption is determined by the characteristic of the households and the type of fuels is determined outside the household [8].

Table 5. Major factor that influence wood fuel consumption.

a) Model Summary

\begin{tabular}{lllll}
\hline Model & R & R Square & Adjusted R Square & Std. Error of the Estimate \\
\hline $.736 a$ & .411 & .319 & .706 \\
\hline
\end{tabular}

a Predictors: (constant), Household size.

b) $A N O V A$

\begin{tabular}{lllll}
\hline Model & Sum of Squares & Df & Mean Square & F \\
\hline Regression & 28.705 & 1 & 28.705 & 57.524 \\
1 Residual & 174.655 & 350 & .499 & \\
Total & 203.361 & 351 & & \\
\hline
\end{tabular}

a) Dependent Variable: What is the quantity of wood fuel use by your household weekly?

b) Predictors: (Constant), Household Size.

Source: field Survey, Niger State, 2018.

In the model summary, (Table 5a), R-square is .411, meaning $41.1 \%$ of the variation from the dependent variable (wood fuel demand) can be explained by variation in the independent variable (Household size). The remaining 58.9\% can be explained by other factors that were excluded (income, educational level, availability of modern fuels and so on) and others that are not in the model. With these results, it can be concluded that though factors such as income, education level of the head of household, government policies (e.g. deregulation of the oil sector may affect the oil product prices), prices of modern fuel sources and so on can influence the demand for wood fuel products by the households, the household size have strong predictive powers, as this variable alone accounts for about $41.1 \%$ of the variation in wood fuel demand.

ANOVA (Table 5b) reveals that the regression equation is significant. It implies that, at least one parameter of the model is significant.

Table 6. Coefficients.

\begin{tabular}{llllc}
\hline \multirow{2}{*}{ Model } & \multicolumn{2}{l}{ Unstandardized Coefficients } & \multicolumn{2}{c}{ Standardized Coefficient } \\
\cline { 2 - 4 } & B & Std. Error & Beta & Sig. \\
\hline (Constant) & 1.013 & .079 & & 12.766 \\
1 Household Size & .279 & .037 & .0376 & 7.584 \\
\hline
\end{tabular}

a. Dependent Variable: What is the quantity of wood fuel use by your household weekly?

$\mathrm{R}=0.736, \mathrm{R}^{2}=0.411$.

Source: field Survey, Niger State, 2018.

Table 7. Excluded Variables.

\begin{tabular}{lcccc}
\hline Model & Beta In & T & Sig. & Partial Correlation \\
& $\begin{array}{l}\text { Collinearity } \\
\text { Statistics Tolerance }\end{array}$ & .988 \\
Monthly Income of household head (to the nearest 1000) & $.061 \mathrm{~b}$ & 1.226 & .221 & .065 \\
Educational Level of Household head & $-.014 \mathrm{~b}$ & -.270 & .787 & -.014 \\
\hline
\end{tabular}

a. Dependent Variable: What is the quantity of wood fuel use by our household weekly?

b. Predictors in the Model: (constant), Household Size.

Source: field Survey, Niger State, 2018.

From the coefficients table (Table 6), it shows that wood fuel demand parameter, that is, $\beta$, is significant, since the $p$ value is 0.000 and the household size parameter is as well significant since the $\mathrm{p}$-value is 0.000 . Given the coefficients ( $\beta=1.013$ and $\beta 1=0.279)$, with the betas not equal to zero. A zero $(0)$ coefficient means that the value of the dependent variable (wood fuel demand) does not consistently differ when the value of the independent variable (household size) increases.

Table 7 (table of excluded variables) shows that we can conclude that household size have more significant impact on the demand of wood fuel products compared to others (income and educational level of household head) variables in the model. The ANOVA table and the coefficient table 
have shown that the model is significant since all the pvalues are less than 0.05 and it invariably means that the parameter of household size in determining the demand of wood fuel is significant. Many Authors [6, 21, 1, 23] stressed that various factors influence household choices of domestic energy use and most of them mostly points to income level amongst others as the major reason for over dependence on wood fuel for energy use.

In this study and deduced form table 7 (model Summary), household size instead of income was the most important factor that influence the demand for wood fuel in Niger State. This is true, may be as a result of low income with most of the households and ever increasing demand for domestic energy. Equally important may be the fact that most of the modern energy sources that are desired by those with high income are not available in most of Niger State especially electricity. Again most of the households are large and they require energy for cooking, heating and lighting and whether income is low may not necessarily reduce demand for wood fuel.

The over-dependence on wood fuel for energy is chiefly because of its relatively low prices and easy accessibility. Other reasons are constraints in the supply of the conventional fuel and the growing population with a larger segment still falling below incomes that cannot afford the cost of conventional fuels [14]. There is relationship between household income and energy use, there is usually a transition by urban users from heavy use of fuel wood to more convenient fuels as income rise. Charcoal is often the main 'transition' fuel to which they shift first. This may be one of the many reasons why in Niger State household size is more significant than income, since a shift from fire wood to charcoal is still within the broader limit (wood fuel) which is the focus of this study and as such, income has not change the source of the energy used by the majority of the households.

[4] Stressed that in Africa there is strong growth in urban consumption of wood fuels mainly charcoal, owing to persistently low incomes, they also argued that in most studies the effect of income on fuel wood consumption turns out to be small, irrespective of how income is measured.

[1] In their study of household domestic energy consumption in Minna, Niger State, indicated that household consumption of domestic energy corroborated with "energy ladder" that implies that households consumes less costly energy and less conventional (biomass) energy, of immediate price and quality to more expensive highly convenient types of energy (LPG, electricity) as their income increases and or habits changes over time, but the inflation rate has changed the whole situation as households depend on biomas (fuel wood and charcoal especially) to beat the effects of inflation. The inflation issue raised by [1] further explains the conclusion by this study that indicated that household size rather than income is the most important factor that influences the demand for wood fuel sources in Niger State.

\subsection{Socio-Economic Effects of Wood Fuel Utilization}

Wood fuel utilization would have created some socioeconomic effects on households in Niger State. This section identifies and explains both social and economic effects of wood fuel utilization in Niger State. The method of data analyses is based on Pearson's correlation and regression.

Table 8. Result of the Correlation Analyses.

\begin{tabular}{llll}
\hline & & Socio-economic effect & Wood Fuel Utilization \\
\hline Socio-economic Effect & Pearson & 1 & .971 \\
& Correlation & & \\
& Sig. (2-tailed) & & .000 \\
& $\mathrm{~N}$ & 361 & .971 \\
Wood Fuel Utilization & Pearson & & 361 \\
& Correlation & .000 & 1 \\
\hline
\end{tabular}

Source: field Survey, Niger State, 2018.

The result on Table 8, shows high level of relationship between socio-economic effect and wood fuel utilization in Niger State. The Pearson's value (0.971) indicates a high positive relationship between the duo. However, the p-value (0.000) which is less than 0.05 level of significance signifies that the null hypothesis should be rejected. This implies that the relationship that exists between socio-economic effect and wood fuel utilization is significant at $95 \%$ confidence limit.

Table 9. The Model Summary.

\begin{tabular}{lllll}
\hline Model & R & R Square & Adjusted R Square & Std. Error of the estimate \\
\hline & $.971^{\mathrm{a}}$ & .943 & .943 \\
\hline
\end{tabular}

Source: field Survey, Niger State, 2018.

From the Table 9, the $\mathrm{R}$ value shows the linear relationship between the dependent and independent variables with 
correlation $=(0.971)$. This implies a strong positive correlation between socio-economic attributes and wood fuel utilization in Niger state and the R square value of 0.943 (94\%) of variation in the dependent variable (socio-economic) is been explained by the independent variable (wood fuel utilization). This result is in line with [15] who observed that in Zimbabwe (Masvingo City) wood fuel poachers have to transport their products from distant areas due to their increasing scarcity in the nearby woodlands. Their scarcity in the vicinity has also forced some poachers to resort to the indiscriminate cutting down of unfavorable species. A holistic understanding of the economic systems that perpetuate consumption of wood fuel and lead to economic impacts provides better evidence for policy makers interested in addressing efficient energy use [22].

\section{Conclusions and Recommendations}

The following conclusions and recommendations are made based on the findings.

Since the economic status of the households are low, coupled with non-availability of modern fuels in Niger State, the most appropriate strategies for improving household energy services in the study area should be those targeted at improving the household fuel mix proportions as opposed to those aimed at completely replacing one type of fuel by another.

There should be general economic development particularly in urban areas which will bring income growth, this will to some extent trigger fuel switching and invariably reduce dependence on wood fuel. The study did not consider consumption of wood fuel in Niger State for a long period, but it is believed that all things being equal wood fuel consumption will continue to increase in the long run. It is therefore imperative for government to reduce the pump prices of kerosene and other fuels so that over dependence on wood fuel will be reduced.

\section{References}

[1] Abd'razack, N. T. A.; Medayese, S. O.; Martins, K. V. I.; Idowu, O. O.; Adeleye, B. M. and Bello, L. O. (2012). An Appraisal of Household Domestic Energy Consumption in Minna, Nigeria. Journal of Environment Science, Toxicology and Food Technology. 2 (5), 16-24.

[2] Ardayfio-Schandorf, E. (n.d). The fuel wood energy crises in sub-saharan Africa. United Nation's Website: retrived on January 10, 2013.

[3] Aina. O. I. and Odebiyi, A. 1. (1998) Domestic Energy Crises in Nigeria. Impact on Women and Family Welfare. Africa Economic History, 26, 1-14.

[4] Arnold, J. E. M.; Kohlm, G. and Persson, R. (2006) Wood fuels, livelihoods, and policy interventions: Changing Perspectives. World development 34. 596-611.

[5] Arnold, M. and Persson, R. (2003). Reassessing the Fuelwood Situation in Developing Countries, International Forestry
Review. 5 (4), 379-383.

[6] Atyi, R. E., Poufoun, J. N; Awono, M, J-P.; Manjeli, A. N. and Kankeu, R. S. (2016) Economic and Social Importance of Fuelwood in Cameroon. International Forestry Review. 18 (1), 52-63.

[7] Audu, E. B. (2013). Fuel wood consumption and desertification in Nigeria. International Journal of Science and Technology. 3 (1), 1-5.

[8] Charles, A. T. (1991). Bio-Socio-economic dynamics and multidisciplinary models in small- scale fisheries research. In J. R. Durand, J. Lemalle and J. Weber (Eds). Proceedings of the Conference on Research in Small-Scale fisheries, Paris, ORSTOM. 15.

[9] Couture, S.; Garcia, S. and Reynaud, A. (2009) Household Energy Choices and Fuel wood Consumption: An Econometric Approach to the French Data.

[10] Gupta, G. G. and Kohlm G. (2006). Preference to Domestic Fuel: Analysis with Socio- Economic Factor and Ranking in Kolkata India. Econological Economics 57: 107-121.

[11] Jibrin, A. and Jaiyeoba, 1. A. (2013) Characteristics of structural composition and diversity of vegetation in the Kpashimi forest reserve, Niger State. Journal of Geography and Geology. 5 (2), 75-84.

[12] Kennedy-Darling, J., Hoyt, N.; Kurao, K. And Ross, A. (2008) The energy crisis of Nigeria: An overview and Implications for the future. The University of Chicago.

[13] Krejcie, R. V. and Morgan, D. W. (1970). Determining Sample Size for Research Activities. Journal of Education and Psychological Measurement. 607-610.

[14] Makinde, B. O. (2017). Wood-fuel Energy Type Dependence in Jos, Plateau State, Nigeria. Journal of Ecology and Environmental Sciences.

[15] Mapira, J. and Munthali, A. (2011). Household Energy Demand: Wood fuel consumption and Peri-urban Deforestation in the City of Masvingo (Zimbabwe). Journal of Sustainable Development in Africa. Vol. 13 (5).

[16] Mamman, A. B. and Abubakar, S. D. (2000) Niger State. In A. B. Mamman, J. O. Oyebanji and S. W. Peters (Eds), Nigeria: A People United, A Future Assured: Survey of states; (Millennium ed.) Abuja: Federal Ministry of Information. 395-414.

[17] 'May-Tobin, C. (2011) 'Wood for Fuel'. The root of the problem. Chapter 8, pp 1-11. Union of Concerned Scientist.

[18] National Bureau of Statistics (2008) Socio-economic Survey on Niger State. Retrieved from http://www.nigerianstat.gov.ng.

[19] Nnaji, C. E.; Uzoma, C. C. and Chukwu, J. O. (2012). Analysis of Factors determining Fuelwood use for cooking by rural households in Nsukka area of Enugu State, Nigeria. Continental Journal Environmental Sciences. 6 (2): 1-6.

[20] Olatinwo, K. B. and Adewumi, M. O. (2012). Energy Consumption of Rural Farming Households in Kwara State, Nigeria. Journal of Sustainable Development in Africa.

[21] Onoja, A. O. and Emodi, A. I. (2012). Economic analysis of fuel wood production and consumption: Evidence from a Nigerian State. British Journal of Management and Economy. 2 (1), 13-23. 
[22] Onoja, A. O. and Idoko,, O. (2012). Econometric Analysis of Factors Influencing Fuel wood demand in Rural and Per-urban Farm Households of Kogi State. Consilience: The Journal of Management and Economics. 2 (1) 13-23.

[23] Peter, M. (2002) Energy Production from Biomass (part 2): Conversion Technologies. Journal of Bioresource Technology. 83 (1) 47-54.

[24] Ravindranath, N. H. and Hall, D. O. (1995) Biomass Energy and Environment - A developing country perspective from India. $61 \mathrm{pp}$, Oxford: Oxford University Press.

[25] Riemtra-Van derHoorst, G., Hoorka, A. I. (2009) 'Fuelwood: The 'other' renewable source for Africa'. Biomass and Bioenergy. 33: 1605-1616.

[26] Sambo, A. S. (2005) 'Renewable Energy for Rural Development: The Nigeria perspective'. ISESCO Science and Technology Vision. 